\title{
Masonry infills with window openings and influence on reinforced concrete frame constructions
}

\author{
D. J. Kakaletsis \\ Technological Educational Institution of Serres, Greece
}

\begin{abstract}
The influence of masonry infills with window openings on the seismic performance of reinforced concrete (RC) frames designed according to current code provisions is investigated. Seven third-scale, single-storey, single-bay frame specimens were tested under reversed cyclic, quasi-static, horizontal loading up to a drift level of $40 \%$. The parameters investigated include the opening location and the infill compressive strength. The assessment of the behaviour of the frames is attempted based on the observed failure modes, strength, stiffness, ductility, energy dissipation capacity, and degradation due to cycling. The experimental results indicate that the location of the window opening must be as near to the edge of the infill as possible in order to provide an improvement in the performance of the infilled frame. Specimens with strong infills exhibited better performance than those with weak infills. For the prediction of the lateral resistance of the studied single-bay, single-storey infilled frames with window openings, a special plastic analysis method has been employed with reference to typical damage modes. Furthermore, a continuous force-deformation model based on an equivalent strut approach is proposed for masonry infill panels containing window openings. The actual properties of the infill are based on the assessment of its lateral resistance by the subtraction of the response of the bare frame from the response of the infilled frame.

Keywords: infilled $R C$ frames, window opening, experimental results, plastic analysis, analytical modelling.
\end{abstract}




\section{Introduction}

A large number of buildings are constructed with masonry infills. For the influence of infill panels on structural performance, controversial results and conclusions have been reported, and henceforth no code provisions or rational guidelines are yet available for the design and safety assessment of such structures. The contribution of infills to lateral stiffness and strength of frames is usually neglected during the design of new buildings. On the other hand, retrofit of older buildings for seismic resistance requires an accurate evaluation of the building response including the contribution of the existing infills [1].

Therefore, appropriate analytical tools for elastic and inelastic analysis of reinforced concrete frames with masonry infills need to be developed and verified through laboratory tests. The lateral load behaviour of frames with masonry infills is usually studied taking into account the influence of the masonry using diagonal struts, which can transfer only the compressive force between the diagonally opposite joints [2]. A key point of this approach is the determination of the actual hysteretic rule parameters of the equivalent diagonal compression strut. The conditions required for a compression strut to develop must also be present. Openings, interface gaps and other discontinuities may affect development of a compression diagonal [3].

A coordinated experimental and analytical research program has been undertaken $[4,5]$. One of the purposes for this study was to experimentally investigate the inelastic behaviour of brick masonry infilled frames so that improved modelling can be developed for the design of new structures with infilled frames. This paper presents the initial results of this effort.

\section{Experimental program}

The experimental program consisted of testing seven single-storey, one-bay, third scale specimens of reinforced concrete frames. Each frame confined a clay brick infill with a window opening. Two parameters were examined, the opening location and the infill strength. The description of the specimens is: a bare frame, a frame with solid weak infill and a frame with solid strong infill (pilot specimens "B", "S" and "IS" respectively); three specimens with weak infill and a window shape opening at various locations, defined by a $\mathrm{x}$ over $l$ ratio equal to $0.167,0.33$ and 0.50 respectively, where $l$ is the length of the masonry infill and $\mathrm{x}$ is the distance between the centreline of the opening and the north edge of the infill (specimens "WX1", "WX2" and "W02" respectively); A further specimen was used with a strong infill and a concentric window shape opening (specimen "IW02"). The window size of all specimens was the same, defined by a $l_{\mathrm{a}}$ over $l$ ratio equal to 0.50 where $l$ is the length of the masonry infill and $l_{\mathrm{a}}$ is the opening width.

The geometric characteristics of the RC frames were the same for all specimens. The elevation, the corresponding cross-sections of the members and the design details for the RC frame specimens are shown in figs. 1(a) and (b). 
(a)
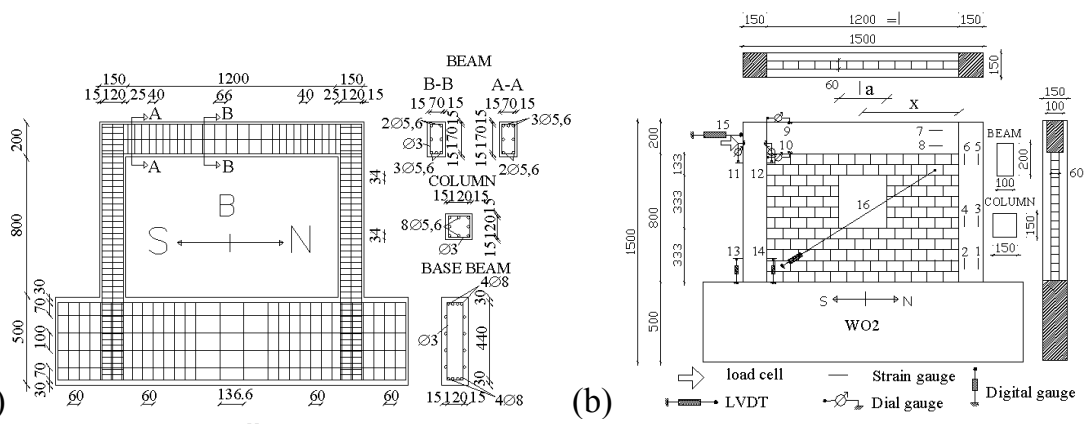

(c)

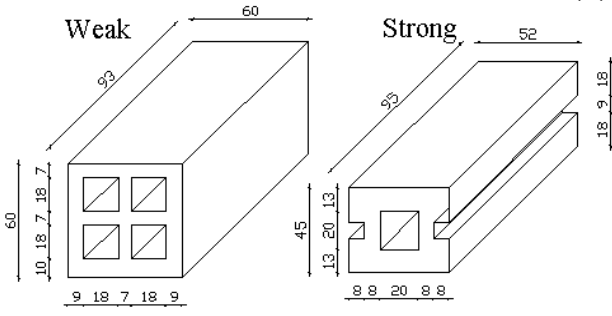

Figure 1: Description of infilled frame specimens (mm): (a) reinforcement detailing of the RC frame model; (b) specimen with window opening and instrumentation; (c) brick unit.

Table 1: $\quad$ Mechanical properties of the materials used (MPa).

\begin{tabular}{|c|c|c|}
\hline \multirow[b]{2}{*}{ Material Properties } & \multicolumn{2}{|c|}{ Masonry type } \\
\hline & $\begin{array}{c}\text { Weak } \\
\mathrm{t}=6 \mathrm{~cm}\end{array}$ & $\begin{array}{c}\text { Strong } \\
\mathrm{t}=5.2 \mathrm{~cm}\end{array}$ \\
\hline \multicolumn{3}{|l|}{ MORTAR } \\
\hline Compressive Strength & 1.53 & 1.75 \\
\hline \multicolumn{3}{|l|}{ BRICK UNITS } \\
\hline Compressive Strength & 3.1 & 26.4 \\
\hline \multicolumn{3}{|l|}{ MASONRY } \\
\hline Compressive Strength $\perp$ to hollows $f_{c}$ & 2.63 & 15.18 \\
\hline Elastic Modulus $\perp$ to hollows & 660.66 & 2837.14 \\
\hline Compressive strength // to hollows $\mathrm{f}_{\mathrm{c} 90}$ & 5.11 & 17.68 \\
\hline Elastic Modulus // to hollows & 670.3 & 540.19 \\
\hline Friction Coefficient & 0.77 & 0.957 \\
\hline Shear Modulus & 259.39 & 351.37 \\
\hline Shear Strength without normal stress $f_{v o}$ & 0.08 & 0.12 \\
\hline Shear Strength with normal stress $f_{v} / f_{n}^{\dagger}$ & $0.38 * / 0.25 *$ & $0.41 * / 0.27 *$ \\
\hline${ }^{\dagger}$ On masonry panels of length $\mathrm{L}_{\mathrm{i}}$ and & $0.33 / 0.22$ & $0.26 / 0.17$ \\
\hline height $\mathrm{H}_{\mathrm{i}}, \mathrm{f}_{\mathrm{v}} / \mathrm{f}_{\mathrm{n}}=\mathrm{L}_{\mathrm{i}} / \mathrm{H}_{\mathrm{i}}$ & $0.39 / 0.30$ & $0.60 / 0.61$ \\
\hline * On full size infills $\mathrm{L} / \mathrm{H}=120 \mathrm{~cm} / 80 \mathrm{~cm}$ & $0.21 / 0.37$ & $0.39 / 0.72$ \\
\hline & $0.20 / 0.73$ & $0.41 / 1.55$ \\
\hline
\end{tabular}



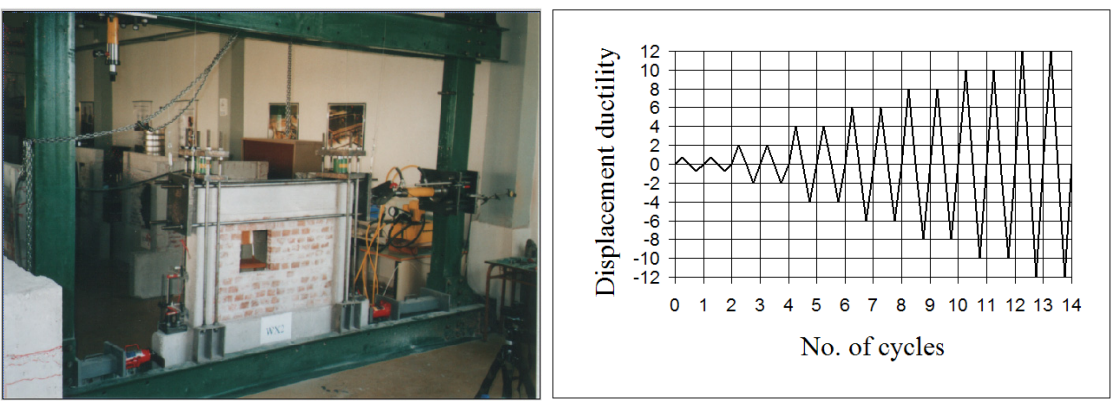

Figure 2: $\quad$ Test setup and loading programme.

The RC frame represented typical ductile concrete construction, particularly structures built in accordance with currently used codes and standards in Greece. Masonry infills had a height/length ratio $\mathrm{h} / l=1 / 1.5$ and were constructed with two selected brick types cut into two halves for complete simulation to the test scale, as shown in fig. 1(c).

Material tests were conducted on concrete, reinforcing steel and masonry samples. The mean compressive strength of the frame concrete was $28.51 \mathrm{MPa}$. The yield stress of longitudinal and transverse steel was 390.47 and $212.2 \mathrm{MPa}$ respectively. The main results of mortar, bricks and infill masonry tests are presented in table 1.

The test setup of the infilled frames is shown in fig. 2. The lateral load was applied by means of a double action hydraulic actuator. The vertical loads applied at the top of the columns were equal to $50 \mathrm{kN}(0.1$ of the ultimate load). One LVDT measured the lateral drift of the frame and one load cell measured the lateral force of the hydraulic actuator. The loading program, as shown in fig. 2, included full reversals of gradually increasing displacements. Two full loading cycles were applied for each displacement level. The cycles started from a ductility level equal to 0.8 corresponding to an amplitude of about $\pm 2 \mathrm{~mm}$ (yield initiation displacement is considered as ductility level $\mu=1$ ).

The main output of the experimental investigation was a load against displacement hysteretic curve for each frame, as shown in figs. 3, 4. The results for reference specimens, "B", "S", "IS", have been reported in reference [5]. The hysteretic response envelopes are shown in fig. 5. It must be pointed out that the hysteretic characteristic values of the weak masonry infill are in some cases higher than the corresponding ones of the strong masonry infill. It may be attributed to the larger units of the weak masonry infill.

\section{Interpretation of experimental results}

From the data shown in table 2 it can be concluded that the location of the opening towards the centre of the span, on the diagonal, resulted to higher decrease of resistance, residual resistance, stiffness, ultimate limit state, ductility factor, normalized cumulative energy dissipation and larger amounts of loss of strength and energy due to cycling loading. In specimens with strong infills, the 
influence of the openings appeared to be less important in resistance, stiffness and normalized cumulative energy dissipation; residual resistance was less decreased, ductility factor and ultimate limit state appeared higher and the loss of strength and energy due to cycling loading appeared smaller.

SPECIMEN WX1

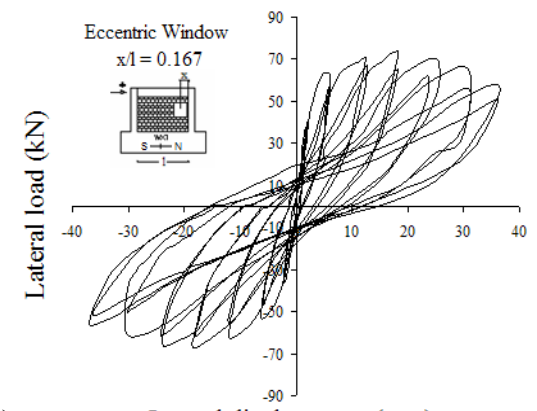

(a)

Lateral displacement ( $\mathrm{mm})$

(b)

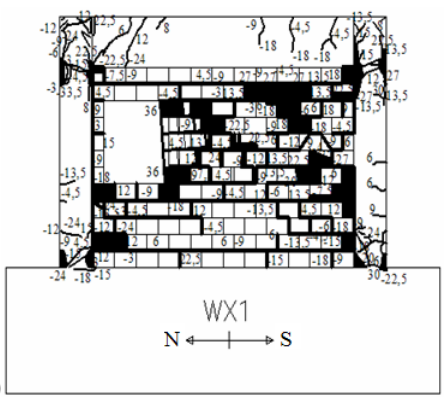

SPECIMEN WX2
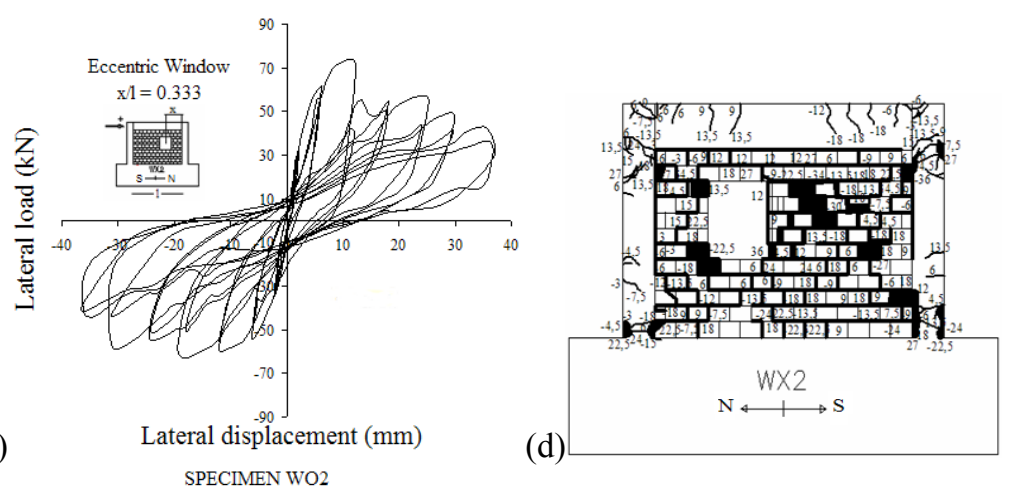

(c) SPECIMEN WO2

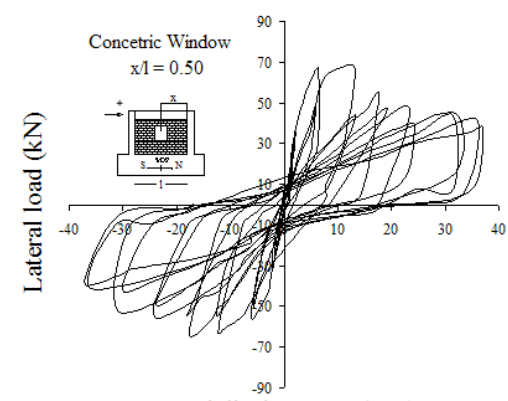

(e) Lateral displacement ( $\mathrm{mm})$

(f)

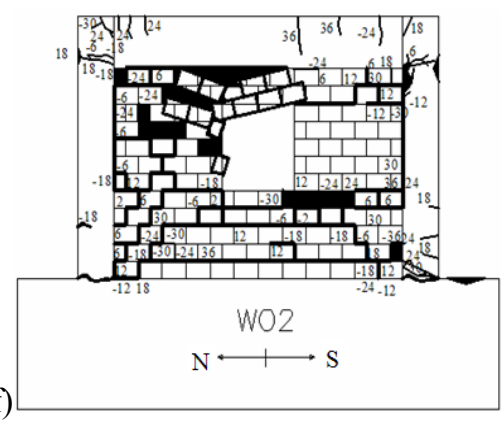

Figure 3: Lateral load - displacement hysteresis curves and failure modes of infilled frame specimens with window openings of various opening locations in weak infill: (a), (b) $\mathrm{x} / \mathrm{l}=0.17$; (c), (d) $\mathrm{x} / \mathrm{l}=0.33$; (e), (f) $\mathrm{x} / \mathrm{l}=0.5$. 
From fig. 5, it can be concluded that increasing the opening eccentricity added average strength increased, loss of stiffness was greater and normalized energy dissipation increased. Strong infills resulted in higher values of average increase of strength, presented lower influence of the opening on the loss of stiffness and decreased normalised energy dissipation with a smoother branch.

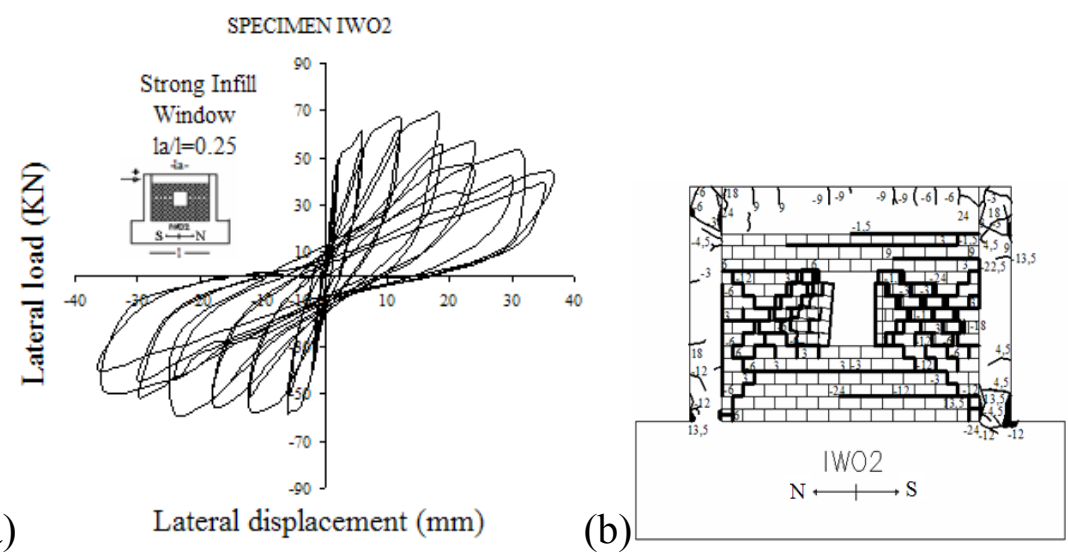

Figure 4: $\quad$ Lateral load - displacement hysteresis curves and failure mode of infilled frame specimen with concentric window in strong infill.

Table 2: Comparison of hysteretic characteristics for test specimens.

\begin{tabular}{|c|c|c|c|c|c|c|c|c|c|c|c|}
\hline Spec. & \begin{tabular}{|c|} 
Structural \\
Morphology
\end{tabular} & $\mathrm{v}$ & $\begin{array}{c}\gamma_{\mathrm{y}} \\
(\% 0)\end{array}$ & $\begin{array}{c}\gamma_{u} \\
(\%)\end{array}$ & $\mathrm{k}$ & $\mathrm{V}_{\text {lim }}$ & $\mu_{0,85}$ & $\beta_{\text {res }}$ & \begin{tabular}{|l}
$\mathrm{V}_{2} / \mathrm{V}_{1}$ \\
(m. v.)
\end{tabular} & $\begin{array}{l}\mathrm{W}_{2} / \mathrm{W}_{1} \\
\text { (m. v.) }\end{array}$ & $\Sigma \mathrm{W} / \Sigma \mathrm{W}_{\mathrm{B}}$ \\
\hline B & Bare frame & 1.00 & 5.06 & 12.09 & 1.00 & 0.74 & 2.81 & 1.00 & 0.89 & 0.84 & 1.00 \\
\hline $\mathrm{S}$ & $\begin{array}{c}\text { Weak solid } \\
\text { infill }\end{array}$ & 1.84 & 2.82 & 9.23 & 2.88 & 0.65 & 4.24 & 1.40 & 0.87 & 0.85 & 1.64 \\
\hline IS & $\begin{array}{c}\text { Strong solid } \\
\text { infill }\end{array}$ & 1.65 & 3.10 & 13.69 & 3.04 & 0.84 & 6.31 & 1.75 & 0.87 & 0.70 & 1.48 \\
\hline WX1 & \begin{tabular}{|c|} 
Weak infill \\
Window \\
$\mathrm{x} / l=0.17$
\end{tabular} & 1.64 & 2.83 & 21.1 & 2.14 & 0.62 & 5.39 & 1.58 & 0.92 & 0.69 & 1.49 \\
\hline WX2 & \begin{tabular}{|c|} 
Weak infill \\
Window \\
$\mathrm{x} / l=0.33$
\end{tabular} & 1.63 & 2.54 & 3.56 & 1.82 & 0.48 & 2.54 & 1.21 & 0.83 & 0.68 & 1.37 \\
\hline WO2 & \begin{tabular}{|c|} 
Weak infill \\
Window \\
$\mathrm{x} / l=0.50$
\end{tabular} & 1.50 & 3.87 & 11.11 & 1.74 & 0.76 & 3.89 & 1.19 & 0.85 & 0.72 & 1.43 \\
\hline IWO2 & $\begin{array}{c}\text { Strong infill } \\
\text { Window } \\
\mathrm{x} / l=0.50\end{array}$ & 1.54 & 2.54 & 20.17 & 2.50 & 0.70 & 6.42 & 1.26 & 0.88 & 0.75 & 1.41 \\
\hline
\end{tabular}

$\mathrm{v}$ : Lateral norm. resistance, $\beta_{\mathrm{res}}$ : Residual nor. resistance, $\gamma_{\mathrm{y}}$ : Serviceability limit, $\gamma_{\mathrm{u}}$ : Ultimate limit, $\mathrm{k}$ : In. norm. stiffness, $\mu_{0,85}$ : Ductility factor, $\Sigma \mathrm{W}$ : cumulative energy, V: max. Recorded force, W: Energy dissipation, 1/2: $1^{\text {st }} / 2^{\text {nd }}$ cycle. 

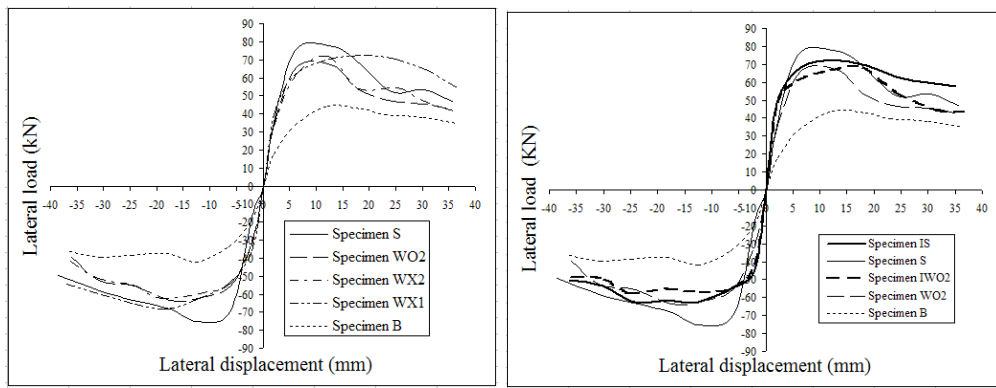

Lateral Load - displacement envelops

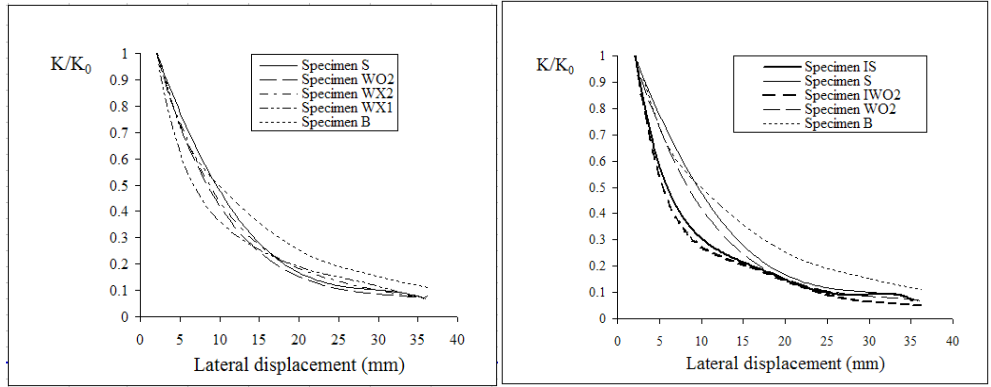

Stiffness of specimens over the initial stiffness
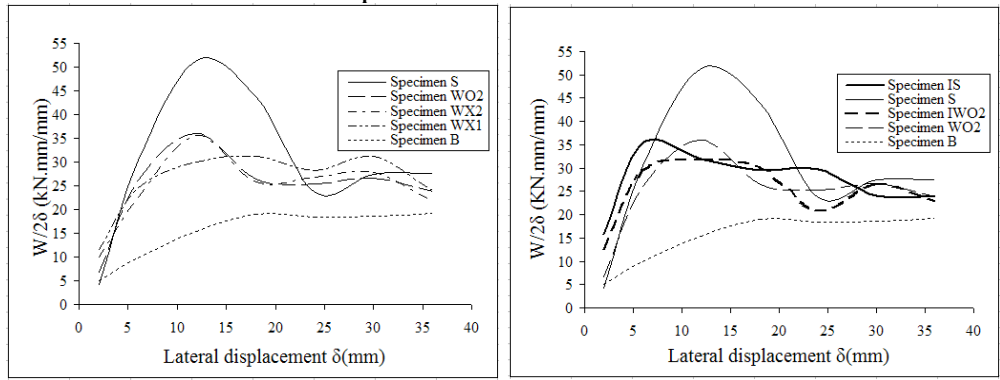

Normalised energy dissipation

(a)

(b)

Figure 5: Comparison of hysteretic characteristics versus imposed displacements: (a) influence of window opening location; (b) influence of masonry strength.

\section{Failure mechanisms for infilled frames}

According to the observed from figs. 3, 4 major damage modes, presented in fig. 6(a), the failure mechanisms of the individual masonry zones formed by the wall segments flanking the openings being loaded diagonally are selected in fig. 6(b). Thus, a system of compressive struts develops within the frame as indicated in fig. 6(c). By applying commonly used engineering strength assessment techniques, analytical formulas have been derived to evaluate the lateral 
resistance, $V_{u}$, of the identified failure mechanisms of the infilled frames with window openings. The lateral resistances of the specimens tested for both analytical derived and experimental values are shown in table 3.

(a)

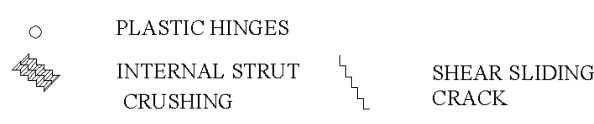

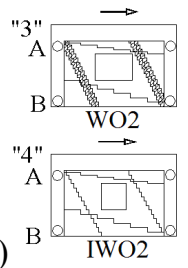

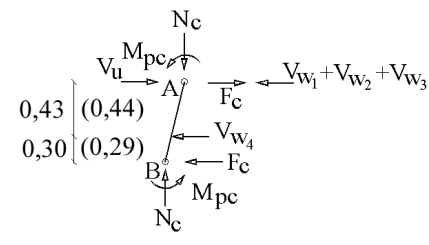

(c)

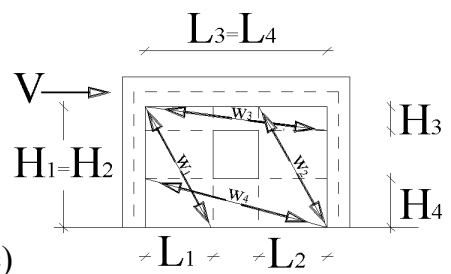

Figure 6: $\quad$ Major damage modes: (a), failure mechanisms; (b) formation of wall segments flanking the opening being loaded diagonally; and corresponding mechanism of secondary struts, (c).

Table 3: $\quad$ Comparison of experimental and analytical result.

\begin{tabular}{|c|c|c|c|c|c|}
\hline Spec. & $\begin{array}{l}\text { Specimen } \\
\text { description }\end{array}$ & $\begin{array}{l}\text { Failure } \\
\text { mechanism }\end{array}$ & $\begin{array}{l}\text { Lateral } \\
\text { resistance } \\
\text { of failure } \\
\text { mechanism } \\
\mathrm{V}_{\mathrm{u}}(\mathrm{kN})\end{array}$ & $\begin{array}{l}\text { Actual } \\
\text { lateral } \\
\text { resistance } \\
\mathrm{V}_{\text {ua }}(\mathrm{kN})\end{array}$ & $\begin{array}{l}\text { Comparison } \\
\left(\mathrm{V}_{\mathrm{ua}}-\mathrm{V}_{\mathrm{u}}\right): \\
\mathrm{V}_{\mathrm{ua}} \\
(\%)\end{array}$ \\
\hline WX1 & $\begin{array}{l}\text { Weak infill } \\
\text { Window } \\
l_{\mathrm{a}} / l=0.25, \mathrm{x} / l=0.17\end{array}$ & "3" & 62.50 & 72.71 & +14 \\
\hline WX2 & $\begin{array}{l}\text { Weak infill } \\
\text { Window } \\
l_{\mathrm{a}} / l=0.25, \mathrm{x} / l=0.33\end{array}$ & "3" & 69.90 & 72.19 & +3.20 \\
\hline WO2 & $\begin{array}{l}\text { Weak infill } \\
\text { Window } \\
l_{\mathrm{a}} / l=0.25, \mathrm{x} / l=0.50\end{array}$ & “3” & 72.32 & 66.56 & -8.70 \\
\hline IWO2 & $\begin{array}{l}\text { Strong infill } \\
\text { Window } \\
l_{\mathrm{a}} / l=0.25, \mathrm{x} / l=0.50\end{array}$ & "4" & 56.11 & 68.13 & +17.60 \\
\hline
\end{tabular}

In the failure mechanism " 3 " for frame with weak infill and window opening, as shown in fig. 6, plastic hinges are assumed to develop at both ends of the columns. The masonry piers $\mathrm{w}_{1}$ and $\mathrm{w}_{2}$ between the left and the right column and the window in the middle of the bay, respectively, reach the diagonal crushing. The masonry zones $\mathrm{w}_{3}$ and $\mathrm{w}_{4}$ above and below the window fail in shear sliding. It is assumed that the lateral resistance of the masonry zone $\mathrm{w}_{4}$ braces the column to a height level with the bottom of the opening and no other significant shear transfer occurs between frame and infill. Taking moment about A, in column $\mathrm{AB}$, results in 


$$
\mathrm{F}_{\mathrm{c}} \cdot \mathrm{h}+\mathrm{V}_{\mathrm{w} 4} \cdot 0,43=2 \cdot \mathrm{M}_{\mathrm{pc}}
$$

where $F_{c}$ is the shear force in each column, $M_{p c}$ is the plastic moment of the column considering the effect of the axial force and $\mathrm{V}_{\mathrm{w} 4}$ is the shear resistance of the wall segment from table 1 . Hence, considering the equilibrium of the frame floor in the horizontal direction results in

$$
\mathrm{V}_{\mathrm{u}}=\mathrm{V}_{\mathrm{w} 1}+\mathrm{V}_{\mathrm{w} 2}+\mathrm{V}_{\mathrm{w} 3}+\mathrm{V}_{\mathrm{w} 4}+2 \cdot \mathrm{F}_{\mathrm{c}}
$$

where $\mathrm{V}_{\mathrm{w} 1}, \mathrm{~V}_{\mathrm{w} 2}$ are the horizontal components of the diagonal strut capacities of the masonry piers $\mathrm{w}_{1}$ and $\mathrm{w}_{2}$ from FEMA 306 [6] and $\mathrm{V}_{\mathrm{w} 3}, \mathrm{~V}_{\mathrm{w} 4}$ are the shear resistances of the masonry segments $\mathrm{w}_{3}$ and $\mathrm{w}_{4}$ from table 1 .

The failure mechanism " 4 " for frame with strong infill and window opening, as shown in fig. 6 , is the same as the previous mechanism " 3 " with the difference that the masonry piers $\mathrm{w}_{1}$ and $\mathrm{w}_{2}$ between the left and the right column and the window in the middle of the bay, respectively, fail in shear sliding. Hence, considering the equilibrium of the frame floor in the horizontal direction results in

$$
\mathrm{V}_{\mathrm{u}}=\mathrm{V}_{\mathrm{w} 1}+\mathrm{V}_{\mathrm{w} 2}+\mathrm{V}_{\mathrm{w} 3}+\mathrm{V}_{\mathrm{w} 4}+2 \cdot \mathrm{F}_{\mathrm{c}}
$$

where the shear resistance of the masonry segments $\mathrm{V}_{\mathrm{w} 1}, \mathrm{~V}_{\mathrm{w} 2}, \mathrm{~V}_{\mathrm{w} 3}, \mathrm{~V}_{\mathrm{w} 4}$ are given from table 1 .
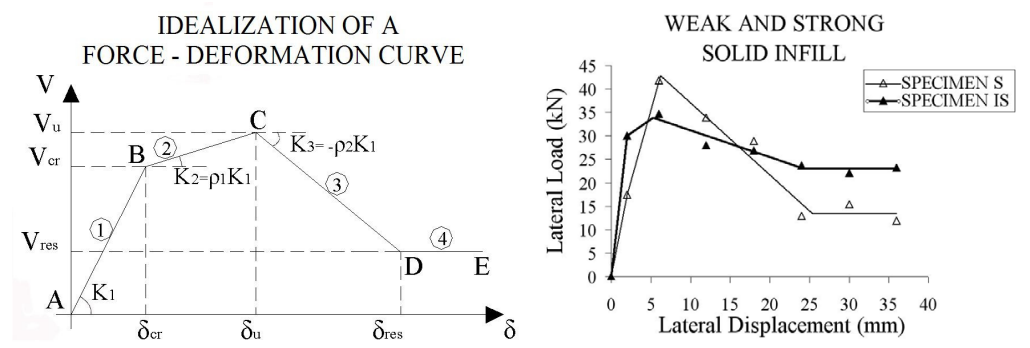

WEAK INFILL WITH

WINDOW OPENING OF VARIOUS OPENING LOCATIONS $\mathrm{x} / \mathrm{l}$
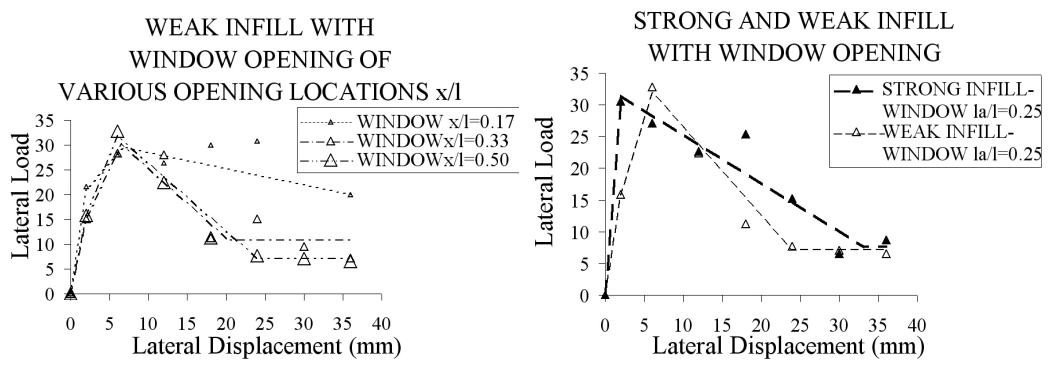

Figure 7: Four-branch approximation of the monotonic force-deformation curve of the infill.

\section{Analytical modelling of masonry infill with windows}

In order to perform a step-by-step force-displacement response analysis or dynamic time-history analysis of large buildings with masonry infilled RC 
frames, a continuous force - deformation model based on an equivalent strut approach is proposed for masonry infill panels containing window openings. The model, which is applicable for degrading elements, can be implemented to replicate a wide range of monotonic force-displacement behaviour, resulting from different design and geometry, by varying the control parameters of the model.

Table 4: Control parameters: (a) of the proposed model and (b) of the Fardis and Panagiotakos [8] model for comparison.

\begin{tabular}{|c|c|c|c|c|c|c|}
\hline $\begin{array}{c}\text { Infill } \\
\text { description } \\
\end{array}$ & $\mathrm{K}_{1} / \mathrm{K}_{1 \mathrm{~S}}$ & $\mathrm{~V}_{\mathrm{u}} / \mathrm{V}_{\mathrm{uS}}$ & $\begin{array}{c}\rho_{1}= \\
\mathrm{K}_{2} / \mathrm{K}_{1} \\
\end{array}$ & $\begin{array}{c}\mathrm{V}_{1}= \\
\mathrm{V}_{\mathrm{cr}} / \mathrm{V}_{\mathrm{u}}\end{array}$ & $\begin{array}{c}-\rho_{2}= \\
K_{3} / K_{1}\end{array}$ & $\begin{array}{c}\mathrm{v}_{2}= \\
\mathrm{V}_{\mathrm{res}} / \mathrm{V}_{\mathrm{u}}\end{array}$ \\
\hline \multicolumn{7}{|c|}{ (a) } \\
\hline $\begin{array}{l}\text { Weak infill } \\
\text { Window } \\
l_{\mathrm{a}} / l=0.50 \\
\mathrm{x} / l=0-0.50\end{array}$ & $1-0.86$ & $1-0.69$ & $0.69-0.54$ & $0.41-0.72$ & $0.17-0.02$ & $0.31-0.23$ \\
\hline $\begin{array}{c}\text { Strong infill } \\
\text { Window } l_{\mathrm{a}} / l=0.50 \\
\mathrm{x} / l=0.0 .50\end{array}$ & $1.71-1.74$ & $0.79-0.49$ & $0.08-1$ & $0.89-1$ & $0.04-0.05$ & $0.68-0.24$ \\
\hline \multicolumn{7}{|c|}{ (b) } \\
\hline Weak solid infill & 1 & 1 & \multirow{2}{*}{$0.20-0.10$} & \multirow{2}{*}{0.77} & \multirow{2}{*}{0.005} & \multirow{2}{*}{ - } \\
\hline Strong solid infill & 1.17 & 0.94 & & & & \\
\hline
\end{tabular}

$l=$ length of masonry infill, $l_{\mathrm{a}}=$ width of opening, $\mathrm{x}=$ distance between opening centreedge of infill, $\mathrm{K}_{1 \mathrm{~S}}(\mathrm{kN} / \mathrm{mm})=$ initial stiffness for the solid weak infill, Vus $(\mathrm{kN})=$ ultimate strength for the solid weak infill, $\mathrm{K} 1 / \mathrm{K} 1 \mathrm{~S}=$ normalized initial stiffness, $\mathrm{Vu} / \mathrm{VuS}=$ normalized ultimate strength, $\rho_{1}=$ hardening ratio of the post-cracking branch, $\mathrm{v}_{1}=$ cracking force $V_{c r}$ to ultimate strength $V_{u}$ ratio, $-\rho_{2}=$ softening ratio of the post-ultimate branch, $\mathrm{v}_{2}=$ residual strength $\mathrm{V}_{\text {res }}$ to ultimate strength $\mathrm{V}_{\mathrm{u}}$ ratio.

From the hysteretic response envelopes presented in fig. 5, the net response of the infills was obtained by subtracting the bare frame load for a given drift from the gross infill frames response. The monotonic force-deformation curve of the panel in shear can be approximated by a four-branch curve having two ascending and one descending linear branches with a horizontal residual strength branch for very large values of the panel deformation, as shown in fig. 7. The curve can be easily defined with the aid of the control parameters showing in table 4.

The control parameters of the proposed continuous model can be determined from the values of $\mathrm{V}_{\mathrm{uS}}$ and $\mathrm{K}_{1 \mathrm{~s}}$ provided by the failure mechanism of the solid infill. Herein, the ultimate load due to compression failure of the equivalent diagonal strut, (horizontal component of the diagonal strut capacity), $\mathrm{V}_{\mathrm{us}}$ and the initial stiffness $\mathrm{K}_{1 \mathrm{~S}}$ for the solid infill can be taken according to [6] where the equivalent strut width is defined using the recommendation given in [2] according to the [7] expressions. The values of the parameters vs the window opening locations and infill strength, provided by various parametric combinations of the specimens, are shown in table 4, together with the parameters of the [8] model, for the solid infill, for comparison. 


\section{Conclusions}

The experimental results indicate that the presence, behaviour and failure of the infills even in the cases with window openings can significantly improve the performance of RC frames in terms of the load resistance, stiffness, ductility and energy - dissipation capacity.

The location of the opening as close to the edge of the infill as possible provides an improvement to the performance of the infilled frame.

Specimens with strong infills exhibit a better performance than those with weak infills.

The concept of compressive struts that develop within the frame by the wall segments flanking the openings being loaded diagonally has been used successfully for the analysis of the specimens tested in this study.

For an alternative non-linear continuous model for masonry infill walls with window, based on the equivalent strut approach, test data can be used to define idealized multi linear load-deformation relations of infill panel with opening.

\section{References}

[1] Dritsos, S. E., Seismic Retrofit of Buildings. A Greek Perspective. Bulletin of the New Zealand Society for Earthquake Engineering, 38(3), pp. 165181, 2005.

[2] FEMA 356, Prestandard and Commentary for the Seismic Rehabilitation of Buildings. Chapter 7: Masonry, Washington, DC, pp. 7.23-7.29, 2000.

[3] Maghaddam, H.A. \& Dowling, P.J., The State of the Art in Infilled Frames, Civil Engineering Department, Imperial College, London, ESEE Research Report No, 87(2), pp. 231-284, 1987.

[4] Kakaletsis, D. J. \& Karayannis, C.G., Experimental investigation of infilled R/C frames with eccentric openings. Structural Engineering and Mechanics, an International Journal, Vol. 26, No3, pp. 231-250, 2007.

[5] Kakaletsis, D.J. \& Karayannis, C.G., Influence of masonry strength and openings on infilled $\mathrm{R} / \mathrm{C}$ frames under cycling loading. Journal of Earthquake Engineering. Vol. 12, No2, pp. 197-221, 2008.

[6] FEMA 306, Evaluation of Earthquake Damaged Concrete and Masonry Wall Buildings - Basic Procedures Manual. Chapter 8: Infilled Frames, prepared by ATC, California, pp. 183-213, 1999.

[7] Mainstone R. J., On the stiffness and strengths of infilled frames. Proceedings of the Institute of Civil Engineers, suppl. (iv), paper 7360S, pp. 57-90, 1971.

[8] Fardis, M. N. \& Panagiotakos, T. B., Seismic design and response of bare and masonry-infilled reinforced concrete buildings. Part II: Infilled structures. Journal of Earthquake Engineering 1(3), pp. 475-503, 1997. 